\title{
SCIDOC
}

\author{
International Journal of Dentistry and Oral Science (IJDOS) \\ ISSN: 2377-8075
}

\section{Role Of Adjacent Soft Tissues In Determining Dimensions Of Maxillary Anterior Teeth}

Research Article

\author{
Dr. Payal Kapse ${ }^{1}$, Dr. Sowmya MK²*
}

${ }^{1}$ Post Graduate Student, Nitte (Deemed to be University), AB Shetty Memorial Institute of Dental Sciences (ABSMIDS), Department of Prosthodontics, Mangalore, India.

${ }^{2}$ Associate Professor, Nitte (Deemed to be University), AB Shetty Memorial Institute of Dental Sciences (ABSMIDS), Department of Prosthodontics, Mangalore, India.

Abstract

Background and Aim of Study: Successful restoration of a tooth within the aesthetic boundaries results in a distinctly positive effect on the patient's self-esteem and quality of life. Thus, the aim of this study was to examine and evaluate the relationship of adjacent facial soft tissue measurements as a guide to the dimensions of maxillary anterior teeth in dentate male and female individuals of Indian origin.

Materials and Methods: This study included a total of 58 dentate subjects i.e. 29 male and 29 female individuals. Various soft tissue landmarks were compared with hard tissue measurements. The obtained data will be analysed using SPSS software version 20. Male and female Groups will be compared by independent Student's t test. Pearson's correlation analysis will be done to assess association between the variables. $\mathrm{p}<0.05$ will be considered as statistically significant.

Results: The difference between the mean value of Philtrum length between male and female found to be significant $(p<0.001)$. The difference between the mean value of upper lip length of male with that of female when compared was also found to be significant $(\mathrm{p}<0.001)$. Similarly, the mean lower lip length of Male was 43.357 and female was 42.528 . Hence, statistically not significant.

Conclusions: The Philtrum length, upper lip length and lower lip length correlates with the width of maxillary lateral incisor in male population. Similarly maxillary central incisor width also correlates between Philtrum length and lower lip length. In female the correlation is found to be negative and weak.

Keywords: Hard Tissue; Soft Tissue; Lip Length; Facial Height; Combined Width Of Maxillary Anterior Teeth.

\section{Introduction}

The human face plays an important role in highlighting human individuality, identity, and personality. In an economically, socially, and professionally competitive world, an overall attractive and pleasant look is becoming a necessity. For many years, it has been believed that the look or appearance of a person imparts to their initial impression, which lasts long. According to Young "it is apparent that beauty, harmony, naturalness, and individuality are major qualities" of aesthetics [1]. The dental appearance is an integral part of facial beauty. This has led to an increased interest in dental aesthetic among dentists and patients $[2,3]$.
Restoring the lost tooth or teeth with proper form, function, occlusion, and aesthetics will be the primary goal of the Prosthodontist. Successful restoration of teeth within the aesthetic boundaries results in a distinctly positive effect on the patient's self-esteem and quality of life $[4,5]$.

Maxillary anterior teeth play a pivotal role in aesthetics since they are visible to a casual observer in unstrained facial activity. A harmonious dentition of an individual has been found to be comprised of proper shape, size, and arrangement of the maxillary anterior teeth [6]. Missing maxillary anterior teeth does not only change the facial appearance but also causes psychological trauma to the individual. Therefore, appropriate selection of size of artificial maxillary anterior teeth is crucial.

\section{*Corresponding Author:}

Dr. Sowmya MK

Associate Professor, Nitte (Deemed to be University), AB Shetty Memorial Institute of Dental Sciences (ABSMIDS), Department of Prosthodontics, Mangalore, India. Tel: +91-9900323937

Fax: +91-0824-2204305

E-mail: drsowmyamk@yahoo.com

Received: September 18, 2021

Accepted: November 13, 2021

Published: November 24, 2021

Citation: Dr. Payal Kapse, Dr. Sowmya MK. Role Of Adjacent Soft Tissues In Determining Dimensions Of Maxillary Anterior Teeth. Int J Dentistry Oral Sci. $2021 ; 8(11): 5117-5122$. doi: http://dx.doi.org/10.19070/2377-8075-210001030

Copyright: Dr. Sowmya $\mathbf{M K}^{\circ}$ 2021. This is an open-access article distributed under the terms of the Creative Commons Attribution License, which permits unrestricted use, distribution and reproduction in any medium, provided the original author and source are credited. 
The natural positioning of the teeth in mouth and their size provides an optimal guide during fabrication of the prosthesis [7, 8]. These pre-extraction records can be profile photograph, radiograph, articulating cast, etc. Selection and replacement of maxillary anterior teeth in the absence of such pre-extraction records is one of the major hurdles in clinical prosthodontics and is usually done arbitrarily [9].

Few studies have reported tooth size variation between different ethnic groups. Various facial guidelines such as bizygomatic, intercommisural, interalar, intercanthal width, lip length, and facial height have been suggested by various authors for deciding the size of the upper anterior teeth, but their reliability is still in question [10-21]. Therefore, speciality of prosthodontics is still in search of a valid and reliable facial measurement for selection of artificial maxillary anterior teeth.

\section{Materials And Methods}

\section{Source Of The Data}

This study was conducted in the Department of Prosthodontics and Crown and Bridge, A. B. Shetty Memorial Institute of Dental Sciences (NIT'TE, deemed to be University), Mangaluru. Institutional Ethical committee approval was obtained for this observational study. This study included a total of 58 dentate subjects, 29 male and 29 female individuals. The sample size was calculated based on [21], $5 \%$ level of significance, $80 \%$ power and an effect size of $0.36, \alpha$-error 0.05 using nMaster software. A written consent was obtained from all the participants included in the study. Measurements were taken with subjects seated in an upright position with unsupported head, natural head position maintained with closed mouth and lip relaxed on the bases of Anthropology. Three soft tissue (facial landmarks) measurements (fig 1)were carried out and marked on a thread. The thread was then measured using Digital Vernier Caliper (Mitutoyo Ltd., UK). a) Philtrum length (PL)was measured and marked between the base of the nose and superior border of the upper lip at midline, ensuring minimal pressure to the tissues [21].

b) Upper lip length (ULL)was measured between the base of the nose and inferior border of the upper lip at midline [21].

c) Lower lip length (LLL)was measured between the superior border of the lower lip and soft tissue Menton (Me) at the midline.

1. Before measuring the inter-commissural width (ICW), the participants were asked toopen and close the mouth widely several times to allow fatigued muscles to relax during the measurement. The lip vermilion was measured between left and right commissure of the mouth using the Digital Vernier Caliper. This was considered as inter-commissural width (ICW). (fig 2)

2. Mesio-distal dimension or width of maxillary central incisor (CIW), lateral incisor (LIW) and canine (CW) was measured intraorally, between interproximal contact points of each tooth with a Digital Vernier Caliper.(fig 3)

3. Length of maxillary central incisor (CIL), lateral incisor (LIL) and canine (CL) was measured intraorally, from the gingival zenith to the incisal edge of the tooth in case of maxillary incisors and up to cusp tip in case of maxillary canines, with the help of Digital Vernier Caliper.(fig 4)

4. Combined width of six maxillary anterior teeth (CWMA) is measured intraorally [38], between the distal surface of the left and right canines using a thread placed at the greatest facial curvature superio-inferiorly and thread was measured using digital Vernier caliper (Mitutoyo Ltd., UK). (fig 5)

The data obtained will be in millimetres. The data will be tabulated and analysed. The obtained data will be then analysed using SPSS software version 20 . The data will be summarized as Mean \pm SD (standard deviation). Male and female Groups will be compared by independent Student's t test. Pearson's correlation analysis will be done to assess association between the variables. $\mathrm{p}<0.05$ will be considered as statistically significant.

Figure 1. Three soft tissue facial landmarks.

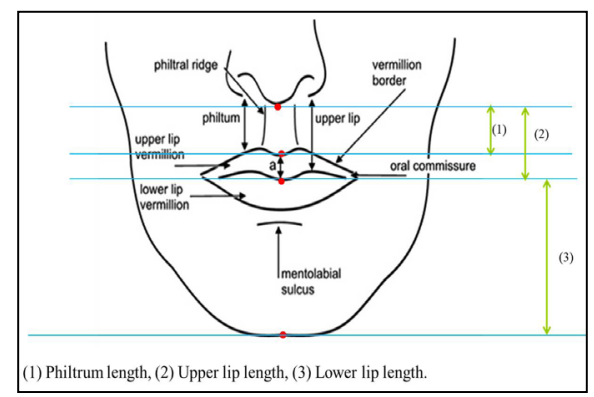

Figure 2. Inter-commissural width.

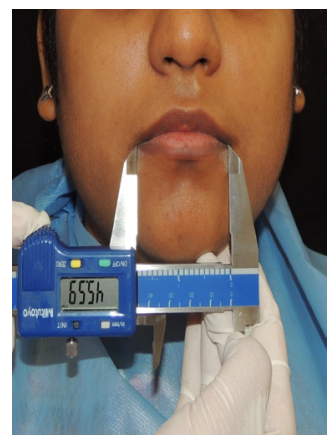


Figure 3. Mesio-distal dimension or width of maxillary anterior teeth.

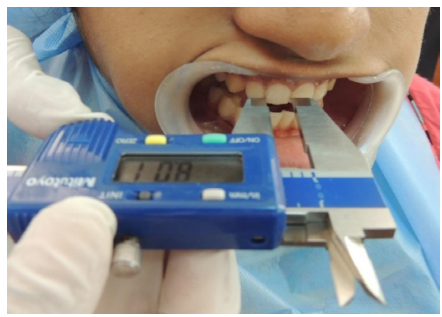

Figure 4. Length of maxillary anterior teeth.

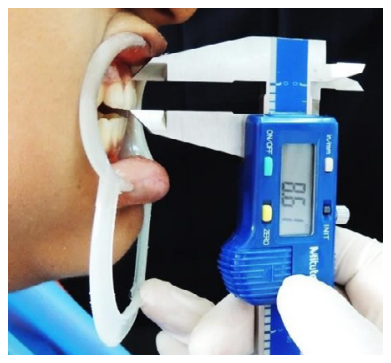

Figure 5. Combined width of six maxillary anterior teeth.

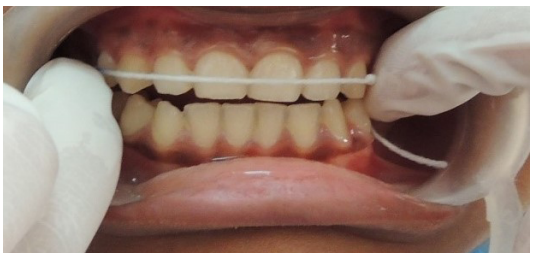

\section{Results}

The subjects selected for the study belonged to an age group between 18 to 25 years. The mean age was 20.86 with the standard deviation of 2.064. The mean Philtrum length in male was $11.584 \mathrm{~mm}$ and that of female was $10.283 \mathrm{~mm}$. The difference between the mean value was found to be significant $(p<0.001)$. Comparison was done using students unpaired t test. The mean upper lip length of male was $20.945 \mathrm{~mm}$ and that of female was $18.42 \mathrm{~mm}$, with the Standard deviation of 2.402 and the difference between the mean value found to be significant $(p<0.001)$. It was compared by using students unpaired t-test. Similarly, the mean lower lip length in case of Male was $43.357 \mathrm{~mm}$ and in case of female it was $42.528 \mathrm{~mm}$. Here the difference is very small and statistically it showed as not significant $(p=0.302)$.

The mean Canine length on the right and left between male and female was compared separately by using student unpaired t-test. The mean Canine lengths on the right side in case of male were $9.288 \mathrm{~mm}$ and 0.902 was the standard deviation, similarly in female it was $9.32 \mathrm{~mm}$ with the Standard deviation of 0.569 . The difference between the mean value found to be not significant $(\mathrm{p}=0.873)$. However, the Canine length on the left of Male was $9.282 \mathrm{~mm}$ and in female it was $9.281 \mathrm{~mm}$. Here the difference is minute and statistically it showed as not significant $(p=0.997)$.

Even while comparing the Canine width right and left between the genders, there was no statistical significance. Canine width right in Male was $7.486 \mathrm{~mm}$ and $7.311 \mathrm{~mm}$ in female. The difference between Male and female was not statistically significant $(p=0.196)$. The mean Canine width on the left side was compared between Male and Female. In which it was $7.49 \mathrm{~mm}$ in male and in Female it was $7.307 \mathrm{~mm}$ and the difference was not statistically significant $(\mathrm{p}=0.185)$.
The length of Lateral incisor on the right and left were also compared between the genders, which showed no statistical significance. In Male the right lateral incisor length was $8.5 \mathrm{~mm}$ with the standard deviation of 0.437 and $8.261 \mathrm{~mm}$ in female with the standard deviation of 0.685 .

The dissimilarity between Male and Female was not statistically significant $(p=0.119)$. Similarly, the mean lateral incisor length at left side was also compared. In Male, lateral incisor length was $8.509 \mathrm{~mm}$ and in Female it was $8.26 \mathrm{~mm}$. This difference was not statistically significant $(\mathrm{p}=0.099)$.

The width of the Lateral incisor on the right and left between the gender was compared by using students unpaired t-test. There was no statistical significance either in the right or left. In Male the lateral incisor width on the right was $6.8 \mathrm{~mm}$ and $6.61 \mathrm{~mm}$ in female with the standard deviation of 0.491 . The difference between Male and Female was not statistically significant $(p=0.092)$. Similarly, the mean lateral incisor width at left side was compared between Male and Female. In Male, lateral incisor width left was $6.764 \mathrm{~mm}$ and in Female it was $6.572 \mathrm{~mm}$. This difference was not statistically significant $(\mathrm{p}=0.08)$ too.

The Central incisor length right and left between the gender was compared to see the difference. We found that there was statistical significance between Male and female in both right and left groups. In Male the Central incisor length at right was $9.771 \mathrm{~mm}$ and $10.368 \mathrm{~mm}$ in female with the standard deviation of 0.468 . The difference between Male and Female was found to be statistically significant $(p=0.002)$. Similarly, the mean Central incisor length at left side was compared between Male and Female. In Male, Central incisor length left was $9.783 \mathrm{~mm}$ and in Female it was $10.396 \mathrm{~mm}$. Hence the difference in the measurement was 
statistically significant $(\mathrm{p}=0.002)$.

The difference between the Width of the Central incisor on the right and left side between the genders when compared was also shown to be statistically significant. In Male the width of the Central incisor on the right was $8.592 \mathrm{~mm}$ and $8.364 \mathrm{~mm}$ in female. The difference between Male and Female was found to be statistically significant $(p=0.026)$. Similarly, the mean width of the Central incisor on the left when compared, in Male it was 8.585 $\mathrm{mm}$ and in Female it was $8.41 \mathrm{~mm}$. Here the difference in the measurement was statistically not significant $(\mathrm{p}=0.086)$.

We have compared the mean combined width of maxillary anterior $(\mathrm{mm})$ between male and female by using students unpaired $\mathrm{t}$ test. The mean width of male was $50.58 \mathrm{~mm}$ and that of female was $48.551 \mathrm{~mm}$. The difference between the mean value found to be significant $(\mathrm{p}=0.002)$.

The mean Inter commissural width ( $\mathrm{mm}$ ) between male and female were compared by using students unpaired $t$ test. The mean Inter commissural width of male was 45.002 and in female it was 43. 911. The difference between the mean value found to be insignificant $(\mathrm{p}=0.107)$.

Correlation between Philtrum length, upper and lower lip length with hard tissue measurements of width were estimated with the Pearson's correlation coefficient (table 1). There is positive correlation between Philtrum lengths with hard tissue measurements in Male. Philtrum length, upper lip length and lower lip length with Maxillary lateral incisor width was found to be moderate positive correlation (0.478 and 0.6) and found to be significant. Similarly maxillary central incisor width also shows moderate correlation between Philtrum length and lower lip length but with upper lip length the correlation is positive and weak (0.281). In female the correlation is found to be negative and weak.
Correlation between the Philtrum length, upper lip length and lower lip length with hard tissue measurements of length was estimated (table 2). Here the correlation is found to be positive in case of Philtrum length and maxillary canine length (0.57) and with maxillary lateral incisor length it was 0.542 . Similarly, lower lip length with maxillary lateral incisor length was found to be 0.584 which was highly significant $(<0.001)$. In female the correlation is weak. The maximum correlation of $r=0.37$ was seen between Philtrum length and maxillary canine length and then with maxillary central incisor length $(r=0.312)$ but the correlation between upper lip length and Lower lip length with maxillary canine length was found to be weak negative. The measurement of lower lip length with maxillary central incisor length was having moderate negative correlation $(\mathrm{r}=-0.475)$.

Correlation between Inter commissural width with combined width of maxillary anterior was done. Inter-commissural width shows positive correlation with the combined width of maxillary anterior teeth for both male and female population $(r=0.806$ and 0.953). (fig 6)

\section{Discussion}

During oral rehabilitation, a dentist must emphasize on development of a pleasant smile and orofacial expression for the patient $[22,23]$. Maxillary anterior teeth are very important in this regard [11]. These teeth must be in harmony with the facial measurements for enhanced facial aesthetics [24]. Once these teeth are properly restored, the patient's self-esteem and self-confidence are often improved $[25,17]$.

Selection of most appropriate size of artificial maxillary anterior teeth has always been a challenge during prosthetic treatment. It becomes even more difficult in absence of pre-extraction records [26]. Various facial measurements have been suggested in the literature for determining the size of the artificial maxillary anterior

Figure 6. Correlation between Inter commissural width with combined width of maxillary anterior teeth.

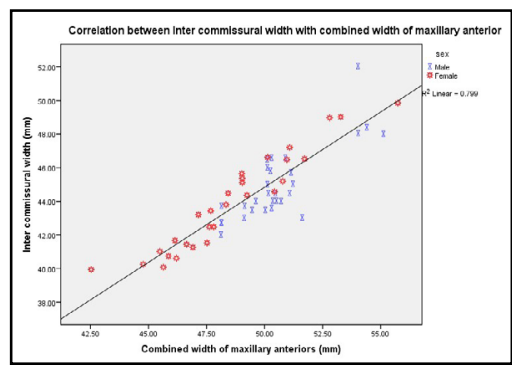

Table 1. Correlation between Philtrum length, Upper lip length and Lower lip length with hard tissue measurements (width).

\begin{tabular}{|c|c|c|c|c|c|c|c|}
\hline \multirow{3}{*}{ Gender } & \multirow{2}{*}{ Length } & \multicolumn{2}{c|}{$\begin{array}{c}\text { Maxillary } \\
\text { Canine width }\end{array}$} & \multicolumn{2}{c|}{$\begin{array}{c}\text { Maxillary Lateral } \\
\text { Incisor width }\end{array}$} & \multicolumn{2}{c|}{$\begin{array}{c}\text { Maxillary Central } \\
\text { incisor width }\end{array}$} \\
\cline { 3 - 9 } & & $\mathbf{r}$ & $\mathbf{p}$ & $\mathbf{r}$ & $\mathbf{p}$ & $\mathbf{r}$ & $\mathbf{p}$ \\
\hline \multirow{3}{*}{ Male } & Philtrum length & 0.27 & 0.157 & 0.478 & $0.009 * *$ & 0.356 & 0.058 \\
\cline { 2 - 9 } & Upper lip length & 0.069 & 0.724 & 0.478 & $0.009 * *$ & 0.281 & 0.14 \\
\cline { 2 - 9 } & Lower Lip length & 0.062 & 0.747 & 0.6 & $0.001 * * *$ & 0.443 & $0.016 *$ \\
\hline \multirow{3}{*}{ Female } & Philtrum length & -0.18 & 0.35 & -0.115 & 0.551 & -0.146 & 0.451 \\
\cline { 2 - 8 } & Upper lip length & -0.16 & 0.407 & 0.034 & 0.863 & -0.121 & 0.531 \\
\cline { 2 - 8 } & Lower Lip length & -0.234 & 0.222 & -0.165 & 0.391 & -0.249 & 0.192 \\
\hline
\end{tabular}


Table 2. Correlation between Philtrum length, Upper lip length and Lower lip length with hard tissue measurements (length).

\begin{tabular}{|c|c|c|c|c|c|c|c|}
\hline \multirow{3}{*}{ Gender } & \multirow{2}{*}{ Length } & \multicolumn{2}{|c|}{$\begin{array}{c}\text { Maxillary Ca- } \\
\text { nine length }\end{array}$} & \multicolumn{2}{c|}{$\begin{array}{c}\text { Maxillary Lateral } \\
\text { Incisor length }\end{array}$} & \multicolumn{2}{c|}{$\begin{array}{c}\text { Maxillary Central } \\
\text { incisor length }\end{array}$} \\
\cline { 3 - 8 } & & $\mathbf{r}$ & $\mathbf{p}$ & $\mathbf{r}$ & $\mathbf{p}$ & $\mathbf{r}$ & $\mathbf{p}$ \\
\hline \multirow{3}{*}{ Male } & Philtrum length & 0.57 & $0.001 * * *$ & 0.542 & $0.002 * *$ & 0.396 & $0.033 *$ \\
\cline { 2 - 8 } & Upper lip length & 0.012 & 0.949 & 0.335 & 0.075 & -0.023 & 0.907 \\
\cline { 2 - 9 } & Lower Lip length & 0.189 & 0.326 & 0.584 & $0.001 * * *$ & 0.185 & 0.336 \\
\hline \multirow{3}{*}{ Female } & Philtrum length & 0.37 & 0.048 & 0.238 & 0.213 & 0.312 & 0.099 \\
\cline { 2 - 8 } & Upper lip length & -0.063 & 0.746 & 0.171 & 0.376 & 0.337 & 0.074 \\
\cline { 2 - 8 } & Lower Lip length & -0.124 & 0.518 & -0.26 & 0.173 & -0.475 & $0.009 * *$ \\
\hline
\end{tabular}

teeth, but their reliability is still in question [15].

Latta, Weaver, and Conkin, (1991) measured the width of the mouth, the Interalar width, the bizigomatic width, and the Interpupilary distance, concluded that more than one variable is needed to predict the width of maxillary anterior teeth [11].

Sellen PN et al. (1993) reviewed the methods used to select artificial anterior teeth for the edentulous individuals. They stated that till date, no universally reliable method of determining tooth form has been found [27].

Al Wazzan KA et al (1995)found no correlation between the width of the mouth and the mesio-distal width of the maxillary anterior teeth in their study [17].

The "Typal form concept" projected by W.R. Hall, 1887 [28]"Tabular Dimension Table Method," was presented by Clapp(1910). This method was based on selecting tooth size from the overall dimension of six anterior teeth and the vertical tooth space present in the patient [29] Williams proposed "Typal form method," in 1914 [30].

"Wavrin Instrumental Guide Technique" (1920), was a combination of Berry's Biometric ratio method and the William's typal form teeth [31]. “Wright's Photometric Method" was based on using a photograph of the patient with natural teeth and establishing a ratio by comparative computation of measurements of like areas of the face and photograph [32].

According to "Anthropometric Cephalic Index Method," proposed by Sears (1941) the width of the upper central incisor could be determined by dividing either the transverse circumference of the head by 13 or the bizygomatic width by 3.3. The tooth length was in proportion to the face length [33]. In White's Concept (1954) artificial teeth were arbitrarily selected to suit the patient's temperament.According to H.Pound's Concept (1954), Width of the maxillary central incisor can be evaluated by dividing the "bizygomatic width (one to one half inches back of the lateral corner of the eyes) by 16. The length of the maxillary central incisor is calculated by dividing the length of the face (distance from the hairline to the lower edge of the bone of the chin with the face at rest) by 16 [22].

Dentogenic Concept of teeth selection was put forth by Frush and Fischer in 1955. This concept has been explained as the pros- thodontic appearance interpretation of three vital factors which every patient possess. The factors are sex, personality, and age of the patient $[34,35]$.

Therefore, this research was carried out as an attempt to understand if there is any correlation exists between soft tissue facial measurements and dimensions of maxillary anterior teeth.

This study assessed the correlation between philtrum length, upper lip length, lower lip length to length and width of the maxillary anterior teeth. It also assessed the correlation between intercommissural width and combined width of maxillary anterior teeth.

According to the results of the present study Philtrum length, upper lip length and lower lip length shows positive correlation with the width of maxillary lateral incisor (0.478 and 0.6) in male population. Similarly maxillary central incisor width also shows positive correlation between Philtrum length and lower lip length (0.443). In female the correlation is found to be negative and weak.

Also, Philtrum length shows positive correlation with maxillary canine length (0.57) and maxillary lateral incisor length (0.542) in male population. Similarly, lower lip length shows positive correlation with the length of maxillary lateral incisor (0.584). In femalepopulation, the correlation was weak, and the maximum correlation was seen between Philtrum length and maxillary canine length and then with maxillary central incisor length. A negative correlation was found between lower lip length and maxillary central incisor length.

A study conducted by Jain S et al. (2018) concluded that Philtrum length can be taken as guide for selecting width of the central incisor in female population. It can also use as guide for selecting height and width of both incisors in male. Lip length can be used as guide for selecting the size of both central and lateral incisors in male, whereas in female it can be used only for selecting lateral incisor size [21].

According to the present study, inter-commissural width shows positive correlation with the combined width of maxillary anterior teeth for both male and female population $(r=0.806$ and 0.953).

Similar results were found in the study by Gomes et al in 2006 . They also found positive correlation between the combined width 
of maxillary anterior teeth and inter-commissural width [1].

Another study conducted by Hussain MW et al. in 2018, concluded that inter-commissural width can be used as a guide for the selection maxillary anterior teeth in Saudi female population [36]. Earlier studies conducted by Kini AY et al. suggested that the Inter-commissural width measured using standardised photographs can be used to determine the combined widths of the anterior teeth accurately [37]. Their results were in accordance with the results of the current study. Whereas the study conducted by Deogade SC et al. suggested that inter-commissural width is not a reliable guide for the selection of artificial maxillary anterior teeth. However, they can be used as an adjunct to other method [38]. There are various controversial statements in literature regarding use of facial measurements as a guide for selection of artificial maxillary anterior teeth. It may differ among different populations as well. The present study can serve as a guide for Indian population.

\section{Conclusion}

Within the limitations of the study, following conclusions were drawn:

1. For male population, Philtrum length and lower lip length can be used as a guide for selecting length and width of the maxillary lateral incisor, width of maxillary central incisor. Philtrum length can also be used as a guide for selecting length of maxillary canine.

2. For female population, Philtrum length can be used as a guide for selecting length of maxillary central incisor and canine. Lower lip length can be used for selecting width of maxillary central incisor.

3. Inter-commissural width was strongly correlated with combined width of maxillary anterior teeth. Therefore, it can serve as guide for selection of artificial maxillary anterior teeth in absence of pre-extraction records.

\section{References}

[1]. Gomes VL, Gonçalves LC, do Prado CJ, Junior IL, de Lima Lucas B. Correlation between facial measurements and the mesiodistal width of the maxillary anterior teeth. J EsthetRestor Dent. 2006;18(4):196-205; discussion 205. PubMed PMID: 16911420

[2]. Morley J, Eubank J. Macroesthetic elements of smile design. J Am Dent Assoc. 2001 Jan;132(1):39-45. PubMed PMID: 11194397.

[3]. Carlsson GE, Johansson A, Johansson AK, Ordell S, Ekbäck G, Unell L. Attitudes toward dental appearance in 50- and 60-Year-old subjects living in Sweden. J EsthetRestor Dent. 2008;20(1):46-55. PubMed PMID: 18237340 .

[4]. Tripathi S, Singh RD, Chand P, Kumar L, Singh GK. A study to correlate various facial landmarks with intercanine distance. Indian J Dent Res. 2018 Jul-Aug;29(4):440-444. PubMed PMID: 30127193.

[5]. Davis LG, Ashworth PD, Spriggs LS. Psychological effects of aesthetic dental treatment. J Dent. 1998 Sep;26(7):547-54. PubMed PMID: 9754742.

[6]. Hasanreisoglu U, Berksun S, Aras K, Arslan I. An analysis of maxillary anterior teeth: facial and dental proportions. J Prosthet Dent. 2005 Dec;94(6):530-8. PubMed PMID: 16316799.

[7]. Keng SB, Foong KW. Maxillary arch and central incisor dimensions of an ethnic Chinese population in relation to complete denture prosthodontics. Int Dent J. 1996 Apr;46(2):103-7. PubMed PMID: 8930682.

[8]. McArthur DR. Determining approximate size of maxillary anterior artificial teeth when mandibular anterior teeth are present. Part I: Size relationship. J Prosthet Dent. 1985 Feb;53(2):216-8. PubMed PMID: 3884788.

[9]. Rajanikanth. AV, Kohli A, Sridevi N et.al. Biometric ratio in estimating width of maxillary anterior teeth with craniofacial landmarks. Int J Health Sci Res. 2019; 9(2):84-89.
[10]. Varjāo FM, Nogueira SS. Intercommissural width in 4 racial groups as a guide for the selection of maxillary anterior teeth in complete dentures. Int J Prosthodont. 2005 Nov-Dec;18(6):513-5. PMID: 16335171.

[11]. Latta GH Jr, Weaver JR, Conkin JE. The relationship between the width of the mouth, interalar width, bizygomatic width, and interpupillary distance in edentulous patients. J Prosthet Dent. 1991 Feb;65(2):250-4. PubMed PMID: 2051360.

[12]. Sülün T, Ergin U, Tuncer N. The nose shape as a predictor of maxillary central and lateral incisor width. Quintessence Int. 2005 Sep;36(8):603-7. PubMed PMID: 16161462.

[13]. Wehner PJ, Hickey JC, Boucher CO. Selection of artificial teeth. J Prosthet Dent 1967;18:222-32.

[14]. Smith BJ. The value of the nose width as an esthetic guide in prosthodontics. J Prosthet Dent. 1975 Nov;34(5):562-73. PubMed PMID: 1058958.

[15]. Hoffman W Jr, Bomberg TJ, Hatch RA. Interalar width as a guide in denture tooth selection. J Prosthet Dent. 1986 Feb;55(2):219-21. PubMed PMID: 3514860.

[16]. Mavroskoufis F, Ritchie GM. Nasal width and incisive papilla as guides for the selection and arrangement of maxillary anterior teeth. J Prosthet Dent. 1981 Jun;45(6):592-7. PubMed PMID: 6941015.

[17]. Al Wazzan KA. The relationship between intercanthal dimension and the widths of maxillary anterior teeth. J Prosthet Dent. 2001 Dec;86(6):608-12. PubMed PMID: 11753312.

[18]. Abdullah MA. Inner canthal distance and geometric progression as a predictor of maxillary central incisor width. J Prosthet Dent. 2002 Jul;88(1):1620. PubMed PMID: 12239474.

[19]. Ahn HJ, Yang HS, Park HO. A study on the selection of the maxillary anterior artificial teeth in Korean adults. J Korean AcadProsthodont 2002;40:484-92.

[20]. Isa ZM, Tawfiq OF, Noor NM, Shamsudheen MI, Rijal OM. Regression methods to investigate the relationship between facial measurements and widths of the maxillary anterior teeth. J Prosthet Dent. 2010 Mar; 103(3):182-8. PubMed PMID: 20188241.

[21]. Jain S, Dhanraj M, Jain AR. Evaluation and correlation between the upper lip length and philtrum length to size of the upper incisors. Drug Invention Today. 2018; 10:562-5.

[22]. Pound E. Lost fine arts in the fallacy of ridges. J Prosthet Dent. 1954;4:616.

[23]. Krajicek DD. Natural appearance for the individual denture patient. The Journal of Prosthetic Dentistry. 1960 Mar 1;10(2):205-14.

[24]. Desjardins RP. Clinical evaluation of the wax trial denture. J Am Dent Assoc. 1982 Feb;104(2):184-90. PubMed PMID: 7035522.

[25]. Wolfart S, Brunzel S, Freitag S, Kern M. Assessment of dental appearance following changes in incisor angulation. Int J Prosthodont. $2004 \mathrm{Mar}-$ Apr;17(2):150-4. PubMed PMID: 15119864

[26]. Grave AM. The frequency of various molds in a sample of natural and artificial dentitions. J Prosthet Dent. 1987 Feb;57(2):194-7. PubMed PMID: 3550053.

[27]. Sellen PN, Jagger DC, Harrison A. Methods used to select artificial anterior teeth for the edentulous patient: a historical overview. Int J Prosthodont. 1999 Jan-Feb;12(1):51-8. PubMed PMID: 10196828

[28]. Hall WR. Shapes and sizes of teeth in American system of dentistry. Lea Bros and co, Philadelphia. 1887:971

[29]. Clapp GW. How the science of esthetic tooth form selection was made easy. J Prosthet Dent. 1955;5:596.

[30]. Williams JL. A new classification of natural and artificial teeth. Dentist supply Co, New York City.1914.

[31]. Wavrin JA. A simple method of classifying face form. Dent Digest. 1920;26:414: 531.

[32]. Wright WH. Selection and arrangement of artificial teeth for complete prosthetic dentures. J Am Dent Assoc. 1936;23:2291-2307.

[33]. Sears VH. Selection of anterior tooth for artificial dentures. J Am Dent Assoc. 1941;28:928.

[34]. Frush JP, Fisher DR. Introduction to dentogenic restorations. J Prosthet dent 1955;5:586-595.

[35]. Frush JP, Fisher RD. The dynesthetic interpretation of dentogenic concept. J Prosthet Den. 1958;8:558-581.

[36]. Hussain MW, Naqash TA, Al-Shahrani AN, Al-Manie AM, Al-Osbi AM. Inter commissural width as a guide for selection of maxillary anterior teeth in Saudi femalepopulation. Int J Appl Dent Sci. 2018;4(2):33-35.

[37]. Kini AY, Angadi GS. Biometric ratio in estimating widths of maxillary anterior teeth derived after correlating anthropometric measurements with dental measurements. Gerodontology. 2013 Jun;30(2):105-11. PubMed PMID: 22540845

[38]. Deogade SC, Mantri SS, Saxena S, Daryani H. Correlation between Combined Width of Maxillary Anterior Teeth, Interpupillary Distance and Intercommissural Width in a Group of Indian People. Int J ProsthodontRestor Dent 2014;4(4):105-111. 